broader criticism of Romanism. ${ }^{143}$ Did Tertullian attack aspects of the Roman Empire? If Tertullian opposed the Roman government, what were his reasons?

The scholarly awareness of Tertullian's anti-Romanism in relation to both the episcopal and the imperial seats raises questions about Tertullian's identities and loyalties. If Tertullian understands himself as being opposed to and outside of the Roman system, then to what system or category does he belong? Because Tertullian evidences a high degree of education and familiarity with GraecoRoman society, history and customs, scholars often assume that he belongs to the elite class of his time, and that he was implicitly supportive of the overall Roman structure, yet such an understanding of Tertullian does not seem to take sufficient account of his anti-Roman sentiments, nor the colonial presence of Tertullian's period.

Given the lack of Tertullian's biographical information agreed upon by scholars, any indication of self-identity evident in Tertullian's writings invites attention. If Tertullian attacks Rome and Romans, then he evidently sees himself as non-Roman. If Tertullian is not Roman, to what category does he belong? One possible answer is that Tertullian wrote with the self-identity of an African. Therefore, in order to give an introduction to Tertullian and his North African context, the following section consists of a brief chronology of both Roman Africa and the Christianization of Roman Africa. Following the chronological surveys, the remaining chapters will employ theories of identity from Social Anthropology in order to re-read Tertullian's context and his writings.

\title{
1.4 The Context of Tertullian: Colonization of Africa
}

Was Tertullian a Tunisian? While one level of discourse might allow scholars to apply such appellations, historians would typically deem such an identification anachronistic. What identities, then, were available to Tertullian, writing from the context of Roman Africa? ${ }^{144}$ In order to explore the possibilities, a brief chronology of Roman colonization of African will prove helpful.

(Lille: A.N.R.T, Université de Lille III, 1992), who finds Tertullian explicitly critical only of Roman idolatry, not the Roman state. It will be suggested below that Tertullian can rhetorically portray Rome in a positive light when it suits his interest and yet still retain an anti-Roman sentiment. It is worth noting that Osborne never cites a passage where Tertullian depicts himself as a "Roman."

143 See bibliography in Osborn, Tertullian, 84; and E. Schüssler Fiorenza, In Memory of Her: $A$ Feminist Theological Reconstruction of Christian Origins, (London: SCM Press, 1983), n. 80; and Fredouille, Tertullian, 446-7.

144 e.g. British? See $A d u$. Iud. 7.4: "...the haunts of the Britons - inaccessible to the Romans, but subjugated to Christ" [...et Britannorum inaccessa Romanis loca Christo uero subdita]. Or Indian? See Apol. 42.1: "We are not Indian Brahmins or Gymnosophists..." [Neque enim Brachmanae aut Indorum gymnosophistae sumus...]. 
Scholars know relatively little about North Africa before Roman colonization and must rely on the reports of Greek and Roman historians. ${ }^{145}$ The local populations, variously referred to as Libyans, Afri (African) and Berbers, consisted of various pastoral and agricultural, urban and rural, as well as oral and literate societies. ${ }^{146}$ Long before Roman occupation, colonization of North Africa involved Phoenicians on their trade route to the Iberian peninsula who established sea ports along the North African coastline (c. $1000 \mathrm{BCE}$ ). The most famous and influential of these ports was Carthage, traditionally said to be founded (c. 814 $\mathrm{BCE}$ ) by Dido. Punic language and customs expanded inland during the centuries before Rome, intermingling language, practices and gods among other indigenous peoples. ${ }^{147}$ With its military and naval superiority, Carthage expanded its own imperial endeavors through much of North Africa. Although peaceable trade with Rome existed as early as $509 \mathrm{BCE}$, Carthage conflicted with Rome resulting in its sequential defeats in the three Punic wars and the ultimate destruction of Carthage (146 BCE). Rome declared the territory around Carthage a Roman province, which became known as Africa Vetus.

North Africa consisted of many peoples and kingdoms, with varying loyalties and identities. One example is the peoples of Numidia: those known as the Massyli also fought against Rome in the second Punic war (218-202 BCE), while the Massaesyli, sided with Rome against Carthage. Later, the Numidian king, Jugurtha, would go to war with Rome, only to be betrayed by his father-inlaw to Rome (104 BCE). In 46 BCE King Juba I would ally Numidia with Pompey, but after his defeat by Caesar Numidia would be incorporated as another province, Africa Nova. The Mauretanians occupied much of modern day Algeria and Morocco, and, after Rome had gained military control of much of North Africa, Caesar Augustus appointed Juba II, who was raised and educated in Rome, as king of the client kingdom, but Caligula would later kill Juba's son (40 $\mathrm{CE})$ and make Mauretania a Roman province. Also of interest are the Gaetulians of the western deserts who sided first against Rome with Jugurtha before allying with Rome and the Garamantes, who themselves generally resided south of Tripolitania, and who later occasionally raided settlements along the coast until subdued by Rome in $70 \mathrm{CE}$.

Long into the Empire, natives of North Africa continued to speak both Punic and Libyan as their native languages and continued to worship both Punic and Libyan gods, and thus, the overlaying of Punic customs creates the first layer in a complex matrix of North African identities. ${ }^{148}$ Throughout North Africa, Punic

145 The following chronology is taken from Raven, Rome; and Anthony R. Birley, The African Emperor: Septimius Severus, rev. ed., (London: B.T. Batsford LTD, 1988); unless otherwise noted. For an archaeological survey of this period, see Quinn, "Roman Africa?"

146 On "Berber" as an Arabic loan-word from Greek, see Fergus Millar, "Local Cultures in the Roman Empire: Libyan, Punic and Latin in Roman Africa," JRS 58 (1968), 128.

147 For "African accent," see Millar, "Local Cultures," 127; and Birley, The African Emperor, 35.

148 On the problems of "Punicization" and the archaeological material data, see Quinn, "Roman Africa?", 23-7. 
influence assimilated into the indigenous societies to the extent that Raven remarks, "...it was the Libyans in the third [century] who finally transformed 'Tyrians into Africans' and, in turn, became the upholders of neo-Punic language and traditions for centuries under the Romans."149

\subsubsection{Romanization of Africa}

Roman colonization of Africa can be understood as a process that penetrated the inland in stages, thereby increasing the grain supply for the empire. ${ }^{150}$ Carthage was refounded in 29 BCE by Octavian - soon to be Augustus, and Africa Vetus and Africa Nova were subsumed under the larger Africa Proconsularis. In the first century, as Rome grew stronger and the need for more grain increased, Roman settlements increased and pushed inland, furthering the acculturation of indigenous people with the Latin language and even Roman religions, largely by transplanting military veterans. Broughton insists that the amalgamation of language and customs came about by trade and not by imperial intent. ${ }^{151}$ By the end of the second century, Rome was well established in Africa, at least in economic terms. However, the inscriptions left by natives under Roman occupation reveal that comparatively few gave up their own language, cults, and customs for the Roman. ${ }^{152}$ Latin became the trade language because most of the colonizers came from Italy.

Despite the imposition of Roman trade, "the cultural situation in Africa was quite complex, much more so than that in most other provinces in the western Roman Empire. There was to begin with an indigenous culture which lasted well into the imperial period." 153 Just as the Punic influence in no way voided the indigenous customs and practices, neither did the Roman victory over Carthage annihilate the Libyo-Punic. ${ }^{154}$ The Punic population returned to the now Roman Carthage of Augustus to form a large percentage of the lower classes. ${ }^{155}$

149 Raven, Rome, 31; it should be noted that Raven in no way discounts the enormous diversity within North Africa.

150 Broughton, The Romanization; the following outline is taken from his work. For the same pattern with other Punic settlements in the Mediterranean, see, for example, Peter van Dommelen, "Punic Persistence: Colonialism and Cultural Identities in Roman Sardinia," in Cultural Identity, ed. Laurence and Berry, 25-48. For further discussion of the process of grain supply from Egypt and Africa Proconsularis, see Phil Perkins, "Power, Culture and Identity in the Roman Economy," in Experiencing Rome, ed. Huskinson, 197-8.

151 The Romanization, $116 \mathrm{ff}$.

152 Ibid, $119 \mathrm{ff}$.

153 Rives, Religion and Authority in Roman Carthage from Augustus to Constantine, (Oxford: Clarendon Press, 1995), 14.

154 Millar, "Local Cultures," on the survival of Punic late into the imperial period.

155 Broughton, The Romanization, 57; and Frend, "Heresy and Schism as Social and National Movements," in Schism. Heresy and Religious Protest, ed. D. Baker, (CUP, 1972), 39-40. 
As Roman trade created more of a Latin presence in North Africa, more Africans assimilated into Roman societal structures. In discussing the Romanization of Africa, Edwin Champlin states, "In Africa, as elsewhere, this [Romanization] was tantamount to urbanization. Therein the ancient cities of the East had a tremendous advantage, and a complementary disadvantage for Africa lay in the vestiges of its strong and alien Punic culture."156 Colonists came to Africa for land with which to raise grain and olives, and with land ownership they hired native workers or re-rented portions resulting in "a society of unprivileged serfs." 157 Whether urban or rural, the new lower classes created by Roman colonization retained many of their indigenous (here meaning, pre-Roman) customs and practices.

\subsubsection{Africanization of Rome}

Well into the second century, a shift occurred where the trend of Rome influencing Africa was reversed, and Africa began to influence Rome. Raven explains, "For most of the second century [the Africans] were to dominate the intellectual life of the Empire, and by the 180s nearly a third of the Roman senate was of African origin." 158 Moreover, in 193 (and until 211) Lucius Septimius Severus became the first African emperor of Rome, followed by his two sons, Geta and Caracalla. Whereas, the first period of Roman presence in Africa could be described as the Romanization of Africa, the latter period could conversely be labeled the Africanization of Rome. ${ }^{159}$

The wealth of Africa Proconsularis allowed many of the provincials to become upwardly mobile in the Roman system. The identities of the upwardly mobile Africans grew in complexity: were they African or were they Roman? Raven writes, "They remained loyal to their native cities; individual senators frequently became the patrons of their birthplaces, interceding with the Emperors to raise them from municipium to colonia, or pleading for favors for compatriots newly arrived in Rome." 160 As will be evidenced below, in some instances loyalties were not so clear, creating complex identities for the upwardly mobile Africans.

Africa of the later empire was riddled with political instability, and the indigenous populations varied widely in their allegiances. Septimius Severus came to power by defeating his rivals Pescinius Niger, an Italian officer in Syria,

156 Fronto and Antonine Rome, (HUP, 1980), 12. For more on urbanization during this time, see Phil Perkins and Lisa Nevett, "Urbanism and Urbanization in the Roman World," in Experiencing Rome, ed. Huskinson, 213-244.

157 Broughton, Romanization, 227; cf. Mattingly, “Africa, a Landscape of Opportunity?” in Dialogues, ed. Mattingly, 124-6.

158 Rome, 122.

159 See Birley, The African Emperor, 83, for examples of "the advance of Africans."

160 Ibid, 126. 
and Clodius Albinus, an African general in Britian, and he ruled by transferring power from senators to the military. His son and successor was murdered by Macrinus, a Mauretanian who briefly became emperor. Emperors who succeeded him also met untimely deaths, including Maximinus Thrax who was killed (238 $\mathrm{CE}$ ) in an uprising that originated in Africa. Gordian I, himself probably of Roman descent and a proconsul of Africa, was named emperor by leaders of a revolt in Africa that consisted largely of indigenous and lower class peoples in and around Carthage. Although Gordian and his son, Gordian II, were defeated, Gordian III would be appointed emperor, only to be challenged by another indigenous revolt in Africa, led by the proconsul Sabinianus (240) who was swiftly defeated. Roman officials would also have to face repeated revolts on the borders of Africa Proconsularis for the following decades. Firmus, from Mauretania, led an indigenous revolt that was suppressed (375) by Rome with the help of Firmus' brother, Gildo. Later, Gildo himelf rebelled against Rome (397), mustering a large following in Africa before being defeated by the emperor who was aided by Gildo and Firmus' brother, Mascezel.

The invasion of the Vandals (428) of the fifth century and the Byzantine reconquest saw the wealth and prosperity of the provincials depleted. The constant turmoil between the empire and the indigenous peoples preceeded the Arabian re-colonization of Africa in the seventh century. Looking back over the entire period, Cherry states, "Putting even the best face on the Romans' actions in the region, it is hard not to conclude, with Broughton, that their only identifiable policy in the frontier-zone is one of 'exploitation'... [resulting in] little immigration into the frontier-zone; hardly any change in native economic structures; limited interaction between the intrusive and indigenous cultures." 161 Cherry is echoing the argument of Broughton, "The Romans adapted themselves to Africa; they gave her peace, and made her prosperous, but they never made her Roman." 162 The historical data suggests that around and amidst the numerous Roman colonial centers in North Africa remained a vast plethora of indigenous communities that retained much of their pre-Roman practices and customs.

\subsection{The Context of Tertullian: Christianization of Roman Africa}

While Tertullian is the first Christian from the context of North Africa whose writings are extant, he writes from within an already prevalent Christian community. How was North Africa evangelized, and to what extent? What were the demographics of the first Christian churches and what changes did they undergo in their history?

161 Frontier, 73.

162 The Romanization, 227-8. Similarly, see Dommelen, "Punic Persistence," 25-48, for the Punic settlement in Sardinia, which was "Romanized" much earlier militarily, but remained Punic in "material culture." 